Proceedings of the Prehistoric Society, 42, 1976, pp. 241-262

\title{
The Plain of Western Macedonia and the Neolithic Site of Nea Nikomedeia
}

\author{
By JoHN BINTLIFF ${ }^{1}$
}

Summary. The Plain of Macedon, North Greece, has seen remarkable changes in its physical geography during the Holocene. The significance of these changes for prehistoric and historic settlement is evaluated, with particular reference to the Neolithic site of Nea Nikomedeia. This reinterpretation contrasts dramatically with previous studies of the Plain's development and with the prehistoric environment postulated by the excavators of Nikomedeia.

From ancient Pella, Philip and Alexander the Great ruled the Macedonian Kingdom. The approximate location of Pella was known by the late eighteenth century A.D. on the southern rim of a very extensive area of Miocene marls and sands, not far from the west bank of the Axios river. Then it lay near the northern shore of the Giannitsa lake, on the hilly rim of the Macedonia alluvial plain.

From field observations around the presumed site of Pella, and from careful scrutiny of Classical references, geographers in the nineteenth and early twentieth centuries A.D. claimed that the alluvial plain was a very recent creation, and as late as the fifth century B.c. a good part of it formed an extension of the Thermaic Gulf, with Pella a port at its head. Pella is now separate from the sea by $30 \mathrm{~km}$ of alluvial plain. (Cousinery 1831; Ilitscheff 1899; Cvijic 1908). The most significant publication came in 1908 with Adolf Struck's Makedonische Fahrten (vol. 2). He summarized the field evidence, and historical records, for dramatic landscape changes in the Macedonian Plain, with reconstructions of the Plain at various growth stages (fig. 8). After the Classical period alluviation was rapid in the Gulf, the present coastline being almost reached, in places, by Late Roman times.

In $1937 \mathrm{E}$. Oberhummer criticised these maps for exaggerated extension of the Gulf and contradictions with details in ancient sources. Nonetheless, we find Struck's illustrations in Casson's Macedonia, Thrace and Illyria (1926), and when Petsas discusses excavations at Pella (1960), and Rodden (1964), Shackleton (1970) and Bottema (1974) present their studies of the prehistoric Plain, Struck is the guideline to the geographical development of the area (fig. 6).

\section{The Site of Nea Nikomedeia}

The tell-mound was excavated by a joint Cambridge/Harvard team in $196 \mathrm{r}-3$ (Rodden, et. al., 1962; Rodden, 1964, 1965). The site is a low mound in the western alluvial plain, $8 \mathrm{~km}$ north-east of Verroia (fig. I). Occupation began in the Early Neolithic, with two phases which are in places separated by humus, suggesting possible abandonment. There is a Late Neolithic reoccupation, when a ditch was dug around part, if not all of the settlement rise. After the remarkably early $\mathrm{C}_{14}$ dates for the earliest occupation, averaging $6218 \pm 150$ bc., a more reliable series of dates would place the first Early Neolithic occupation about 5500-5300 bc. (Bottema 1974, 147).

The fauna from the site showed many bovines, and pigs, though caprovines predominated. Floral remains evidenced cultivated emmer, einkorn, barley, lentils, peas and vetch-while acorns and

${ }^{1}$ Address: Corpus Christi College, Cambridge. 


\section{THE PREHISTORIC SOCIETY}

other wild fruits were gathered. Charcoal analysis showed Mediterranean evergreen maquis, timber brought from the uplands, for pollen counts by G. Dimbleby from the site (though in unsatisfactory circumstances) suggested that the landscape was of 'an open nature' (Rodden, et. al. 1962, 275), and that 'open brushwood communities' as today characterised the area (Rodden I964, II3). The high bovine count apparently confirmed a steppe landscape (1962, 274).

Rodden compared the Struck reconstruction of the pre-Classical period with the Admiralty Handbook (1945) reconstruction of the extent of Lake Giannitsa before drainage, reasoning that Nea Nikomedeia must 'have been in close proximity to the coast' (1964, I12). The tell defences were apparently missing on the east, perhaps there was even open water here. The site's shellfish were almost all shallow salt-water, or brackish-water species. Rodden concluded that the first settlers occupied a 'slight knoll on the edge of a marshy lake or inlet' $(1965,84)$ with a moist, almost treeless alluvial plain as a hinterland.

Given the present day quagmire conditions of the plain in winter, occupation is considered seasonal, the community moving regularly to higher ground on the plain edge (Rodden, pers, comm.). A problem remains, explaining the deep foundations of the Early Neolithic settlement, for these are waterlogged today even in summer. Finally, Rodden attributes the curiously restricted period for the alluvial infill of the Gulf, from the $5^{\text {th }}$ century B.c. onwards, to sea level rise since Classical times (1964, 112).

Shackleton (1970) has re-examined the Nikomedeia shellfish remains, confirming their salt and brackish water nature. The shellfish environment underwent seasonal freshwater inundationsindicating estuarine conditions with winter high flow of large rivers as today. The 'water body [was] freely connected with the sea as an estuary and in summer, the water would have had the salinity of the open sea, while in winter the salinity was much reduced by river inflow' (1970, 944). Shackleton assumes that shellfish were carried, unshelled, from close at hand, hence the shell analyses characterise open water bordering the settlement. But if so, it is curious that 'at this particular site we are limited by the fact that shellfish was not an important part of the diet', and 'although shellfish remains are not abundant in the deposits'(943-4).

S. Bottema has published (1974) a comparative pollen study for Northern Greece, including a new core from the former Lake Giannitsa which is compared with the pollen collection studied by Dimbleby from the site levels. From this more elaborate sequence, Bottema challenges the 'openness' of the prehistoric plain, arguing instead a good cover of oak woods. "The first farmers... found the area covered with deciduous forest. . . to the east and northeast, the forest gave way to swamp forest. .. [then]. . . saline meadows (1974, $146-7)$.

\section{Geological Background.}

The Plain of Western Macedonia (North Greece) measures $50 \mathrm{~km}$ east-west, $30 \mathrm{~km}$ north-south. There are three basic relief units: mountain, hill-land and alluvial plain (fig. $\mathbf{r}$ ).

The mountain is predominantly Mesozoic crystalline limestone (fig. 2). The underlying regional tectonic pattern is an alternation of depressed and raised zones, furrows and ridges, within a larger division-the Vardar furrow (Mercier 1973). These features trend NW-SE. The Vardar furrow has undergone continual oceanic submergences when its sub-ridges formed underwater mountains. In the periods of Alpine orogenic activity the sub-ridges rose most actively to dry-land heights, and in the post-orogenic subsidences the sub-furrows experienced most depression relative to their surrounding landscape.

From east to west, within the Vardar furrow, Mercier distinguishes the Peonian sub-furrow (Axios depression, Salonika, W. Chalcidice), Paikon sub-ridge (Mt Paikon), Almopias sub-furrow (Almopias plain, western part of the Macedonian plain proper). The mountains of Vermion and Pieria, rimming the Plain on west and south west, belong to the Pelagonian major ridge zone. 


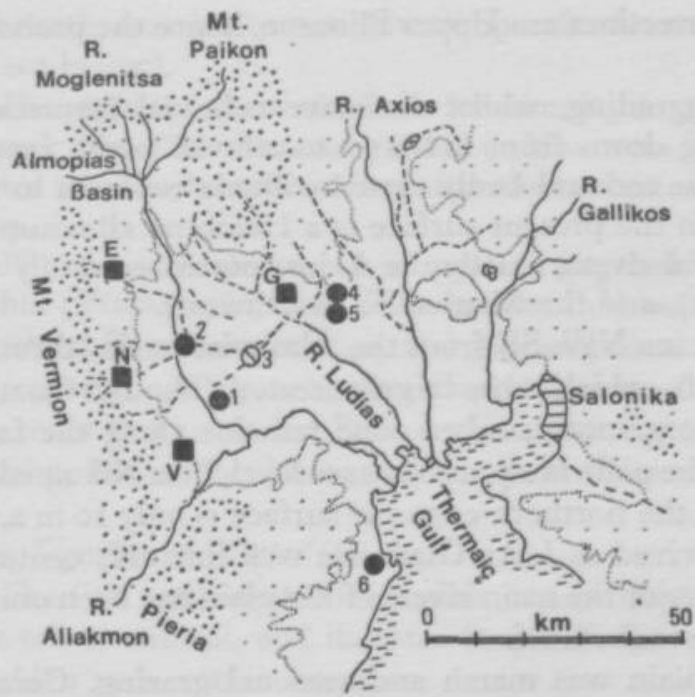

Fig. I

Fig. 1

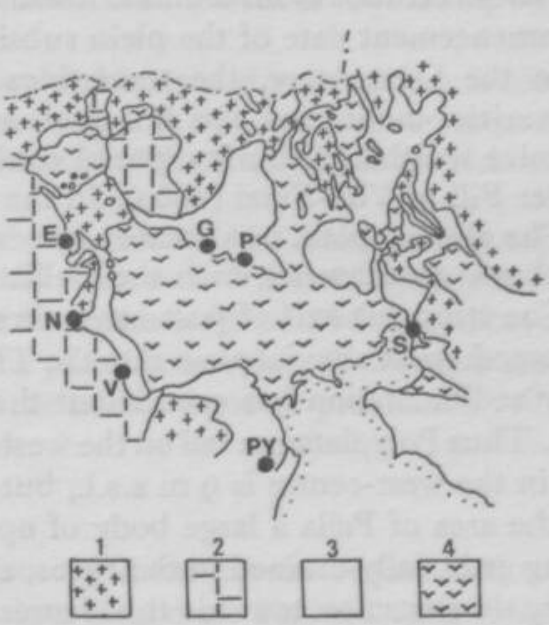

Fig. 2

The Plain of Western Macedonia. Contours at 100 and 600 metres. Key: $x=$ Nea Nikomedeia Tell; $2=$ Polyplatanon Tell; $3=$ Giannitsa Pollen Core; $4=$ Pella; $5=$ Phakos; $6=$ Pydna; $\mathrm{G}=$ Giannitsa; E $=$ Edessa; $\mathrm{N}=$ Naoussa; $\mathrm{V}=$ Verroia.

Fig. 2

Geology of the West Macedonian Plain. Key: $1=$ Metamorphic and igneous rocks; $2=$ Mesozoic cristalline limestone; 3 = Tertiary and Pleistocene sands, silts, marls and travertines; $4=$ Quaternary alluvium. Placenames as in Figure $\mathbf{r}$.

All four sectors remained underwater till the emergence to land of Paikon in the Jurassic; the Pelagonian ridge followed, by the Lower Cretaceous, The intervening furrows remained subsea and by the Middle Cretaceous the sea had invaded all structures hitherto erected, the ridges returning underwater. In the early Tertiary orogeny, all four sectors emerged above the sea. Although considerable post-orogenic subsidence occurred, the sea only recovered a limited area in the Quaternary.

From the Oligocene to the present most of our area experienced continental conditions. The limestone of the submerged phases created mountains in the 'ridge' areas, but was buried by later continental sediments in the furrows. The major Tertiary formation is a Miocene series of soft lacustrine and riverine sands and silts, forming extensive hill-land on all but the north-west side of the plain. This hill-land forms the intermediate zone between mountain and alluvial bottomland, together with Pleistocene weathering deposits and travertines.

In the Pliocene, the region shared Aegean-wide subsidences. The Almopias furrow sank below the limestone mountains and the recent hill-land, and its bordering faultline witnessed volcanic eruptions, preserved in the present alluvial plain as low volcanic hills running south-east from the Almopias basin; the Axios trench was created now by the subsidence of the Peonian furrow, in a southerly trending depression. The area of the present alluvial plain, as a result of these forces, began to subside and separate from mountain and hill-land.

The depressed plain being covered by younger sediments, Pliocene formations are absent at its surface, except for the volcanic extrusions. As the plain sank, lime-rich mountain streams on its west formed waterfalls over the increasing gap. The resultant deposition of calcic beds created extensive travertine terraces and these fertile soils and abundant water sources determine the sites for important 
towns-Verroia, Naoussa and Edessa. The basal travertines are Upper Pliocene, hence the probable commencement date of the plain subsidence.

In the Quaternary, the travertines continue aggrading, whilst extensive colluvial formations within the mountains and hill-land, and spreading down from hill-land to alluvial plain, record massive weathering during glacial conditions. These red and badly sorted colluvia conform to the Older Fill of Vita-Finzi ( 1969 ). In the alluvial plain the present surface is a Holocene alluvium.

The alluvial plain was created by several perennial rivers, chiefly the Axios (north), secondly the Aliakmon (southwest), then the Gallikos (northeast), and the Moglenitsa (northwest).

The strongest axis of post-orogenic subsidence runs NW-SE from the Almopias basin, through the north-west alluvial plain into the Thermaic Gulf-which it has largely created. Though Quaternary sedimentation has evened out the plain, a pronounced sunken zone remains along the fault axis. Thus Polyplatanon tell on the western edge of the plain is $24 \mathrm{~m}$ above sea level, Nea Nikomedeia tell in the west-centre is $9 \mathrm{~m}$ a.s.l., but by Pella on the northern edge the surface is only $10 \mathrm{~m}$ a.s.l. In the area of Pella a large body of openwater survived as Lake Giannitsa well into this century, being artificially drained in the 1920 , and the history of the main rivers of the plain has been one of alternate attraction towards this depression and the main Gulf.

Until recent reclamation much of the alluvial plain was marsh and seasonal grazing. Cereals flourished in the higher and drier areas, but malaria and waterlogging made plain cultivation difficult and dangerous, and local farmers preferred to settle on the plain foothills. Frosts and mists prohibited olive and fruit trees on the plain, but rim settlements were compensated for lengthy distances to plain holdings by flourishing tree crops in the warm, sheltered travertine terraces and Miocene hills surrounding the bottomland (Admiralty, I945, II3-8).

The district was studied by the author in 1974 . The tell of Nikomedeia rises only a couple of metres above grey alluvium and humus-peat, while the excavated levels within the tell disappear beneath the near-horizontal surface of the plain. $100 \mathrm{~m}$ south-west of the mound a recently excavated drainage ditch exhibits the following section (fig. 3 ): below the top of the cutting, at the plain surface, there is $\mathrm{I} \mathrm{m}$ of black to dark brown alluvium and peat. At the base of the cutting, making up the last $50 \mathrm{~cm}$, and forming the floor of the trench, is a white, dense 'clay'. Samples of both formations were collected for analysis.

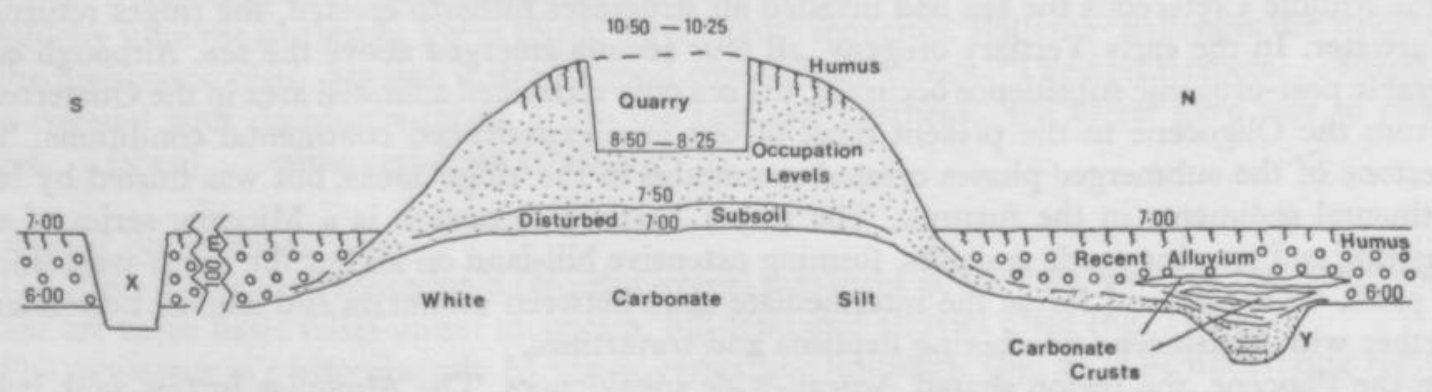

Fig. 3

A cross-section through the Nikomedeia tell and its surrounding landscape. Heights in metres above present sea-level. Key: $\mathrm{X}=$ modern drainage ditch; $\mathrm{Y}=$ Late Neolithic ditch. Not to scale.

The ancient city of Pella is located $c .30 \mathrm{~km} \mathrm{ENE} \mathrm{of} \mathrm{Nikomedeia,} \mathrm{and} \mathrm{on} \mathrm{the} \mathrm{southern} \mathrm{edge} \mathrm{of} \mathrm{the}$ Miocene hills, where they disappear under the alluvial plain (fig. 2). The plain immediately adjacent to Pella is abnormally low, due to its location on the main axis of subsidence, and between Pella and the ancient mound of Phakos, $2 \mathrm{~km}$ out into the plain, the area even after reclamation of the Giannitsa Lake is very boggy underfoot. Available evidence points to similar conditions characterising the early historic and prehistoric periods, with a dry and fertile hinterland of Miocene sediments, and to 


\section{IO. f. Bintliff. THE PLAIN OF WESTERN MACEDONIA}

the south, marsh alternating with open freshwater as far as Phakos, then the sea or a wide shipway to it (see below).

The significance of the Pella location lay in an extensive arable hinterland and harbour facilities. Struck describes the nearby town as Yisannisa 'richest in cereals' $(1908,67)$ and notes an important cereal trade and cereal market after the harvest. Today the hills behind the site of Pella are rich in the crop.

The site was already an important city before King Archelaos moved the Macedonian capital hither (Petsas 1960, I19). The earliest finds are from the Phakos mound. This structure rises like an island from the alluvium, and was long considered an historic construction. Petsas has uncovered Mycenaean pottery, relating this prehistoric settlement to the place Bounomos, or 'cattle pasture', the town that preceded Pella itself on the higher ground to the north. Another prehistoric tell lies nearby, but on the Miocene formations (Petsas 1960, 122).

\section{The Significant White 'Clay'}

The first settlers at Nikomedeia occupied a low knoll. Figure 3 illustrates the sequence through the tell to subsoil, and its inter-face with surrounding alluvium (based on Rodden $1962,269-75$; Rodden pers. comm. 1974).

From an original tell summit at c. 10.25-10.50 m a.s.l., the sequence runs: Recent ploughsoil; Late Neolithic level; weathering; Early Neolithic levels, resting amid fragments of 'clay-marl' from the subsoil, reflecting use of subsoil for house-construction and pits excavated into virgin bedrock of 'clay'; uncontaminated virgin 'clay-marl', yellowy-grey and brown-streaked, appeared at c. 7.50$7.00 \mathrm{~m}$ a.s.l., as a low rise descending towards the tell perimeter. Calculating the depth of the same 'clay-marl' in the nearby drainage ditch at $c .6 \mathrm{~m}$ a.s.1., the natural rise underlying the tell is only $\mathrm{I}-\mathrm{I} .50 \mathrm{~m}$ above its surrounding 'clay' series.

Bottema correlates this marl under the site with a deposit in the Giannitsa core $7.5 \mathrm{~km}$ to the northwest, at $\mathrm{II}-\mathrm{I} 2 \mathrm{~m}$ below sea level (fig. $\mathrm{I}$ ). Both are white 'hard marly clay devoid of pollen' (1974, $\mathrm{I}_{4} \mathrm{I}$ ) and $\mathrm{C}_{1} 4$ dates at both locations place the 'clay' as the last formation laid down before the Holocene. By the 6th millennium bc date of Early Neolithic colonisation, only humus overlay the hillock marl of Nikomedeia, but in the core $c .2 \mathrm{~m}$ of estuarine to shallow saltwater sediments had accumulated above the marl (1974, 147).

From the same figures, and an estimate of the depth of saltwater overlying the sediments at the coring area (determinable from floral inclusions), Bottema calculates that sea level contemporary to the first occupation of the tell-site, was between 6-9 m below present day. [This is a corrected figure from that given by Bottema (1974, 147) due to the author's and Bottema's recalculations]. It is surprising then to find him locating the site 'on the edge of the still-expanding Gulf of Therma', and placing Nikomedeia on his text figures on the coast (1975, 147; see fig. 6), when the tell must have been $\mathrm{I}_{4}-\mathrm{I} 7 \mathrm{~m}$ a.s.1.

One would have to imagine the settlement atop of a cliff c. $50 \mathrm{ft}$. high for such a height to be on the shore (cf. fig. 4). Since it is fairly certain that sea-level was c. $2.5 \mathrm{~m}$ below present in the Classical period (Bintliff $1975^{\mathrm{a}}$, and forthcoming) broadly interpolating between these two approximate sea-

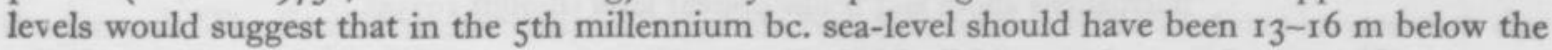
tell. Again, surprisingly, Bottema suggests that the Early Neolithic people were forced to abandon the settlement in the mid 5 th millennium, when rising seawater isolated the hillock (1974, 149).

However the 6th millennium(radiocarbon) ocean level could actually refer to a 7 th millennium B.c. level in calendar years (Renfrew $1973,268-9$ ), therefore this level is reasonably in accordance with a long-term rise in the ocean of $c .1 \mathrm{~m}$ a millennium. This is an exact extrapolation of the known average range over the last $2 \frac{1}{2}$ millennia, but also fits neatly into several published reconstructions of worldwide eustatic movements in the Holocene (fig. 5). 
Bottema identifies the white 'clay' in the basal Giannitsa core with the same sediment underlying human occupation at Nikomedeia $(1974,79,14 \mathrm{r})$. The writer's sample from the nearby ditch, and a sample of overlying alluvium, were examined in Cambridge by Prof. R. West, Mr B. Sparks, Dr R. Chorley and Dr P. Friend.

The white 'clay' is a pure carbonate silt, deposited in stillwater, almost certainly a lacustrine series. A strong case exists for identifying the tell silt with the same formation in the basal core. It is the first formation below Holocene levels (at the tell below its own humus, at the core below $2 \mathrm{~m}$ alluvium). Secondly the post-Alpine geology of the Plain revolves around the NW-SE subsidence axis, strongest between Pella and Nikomedeia. If an enlarged lake existed before the Holocene, it would be predictably deepest in the centre of the depression axis, where lay the recent lake (fig. Io f).

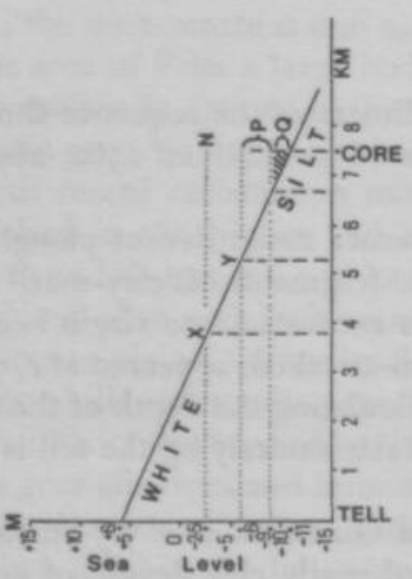

Fig. 4

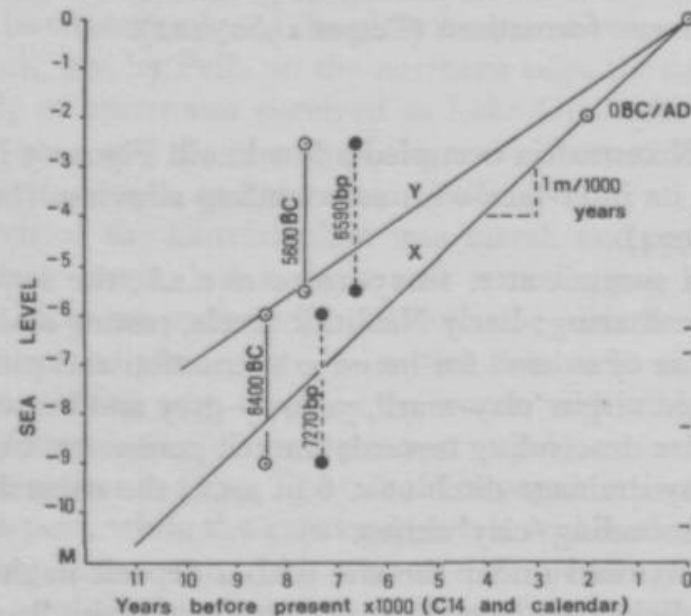

Fig. 5a

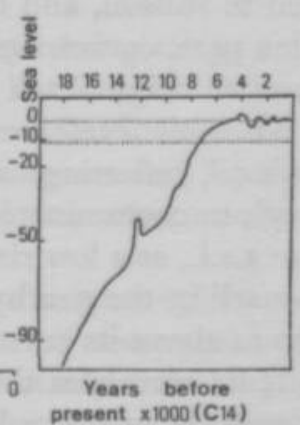

Fig. 5b

Fig. 4

Holocene sea-level rise and the white silt landscape between the vicinity of the Nikomedeia tell ( +6 metres a.s.1.) and the core-site (-1I metres b.s.l.). Sea-levels relative to present ocean height. Key: $Q=$ alluvium above white silt by $7270 \mathrm{bp} ; \mathrm{P}=$ approximate range of sea-level at $7270 \mathrm{bp} ; \mathrm{Y}=$ maximum possible sea encroachment at $7270 \mathrm{bp} ; \mathrm{N}=$ probable ocean height at 500 B.C.; $\mathrm{X}=$ maximum sea encroachment possible at 500 B.C.

Fig. 5

Alternative plots for Holocene ocean rise based on the core-data ( $5 \mathrm{a}: \mathrm{X}$ and $\mathrm{Y}$ ), compared with a generalised worldwide scheme ( $5 \mathrm{~b}$ : after Butzer $197 \mathrm{r}$ ). Sea-levels in metres below present. Vertical bars with solid circles denote the approximate range of sea-level at two points of the core in $\mathrm{Cr}_{1} 4$ years, vertical bars with open circles show the same readings with the $\mathrm{C}_{4} 4$ dates recalibrated. The o B.C./A.D. position is a generalized Mediterranean average. The Y plot in the lower range of the younger dated level is plausible for that level since a peat zone is found slightly higher in the sequence. A combination of both $\mathrm{X}$ and $\mathrm{Y}$ plots best fits the data, giving an overall average of rather less than a metre per millennium eustatic rise over the last 7000 years (CI4).This agrees with a smoothed average from Butzer's worldwide plot ( $5 \mathrm{~b})$, which is preferable to his continuous recent fluctuations above and below present level (Bintliff 1975a).

Interpolating the surface of the white formation, from the level around the tell (c. $6 \mathrm{ma.s.1}$ ), to the level found in the core (c. II m b.s.l.), produces a gentle gradient from the upper plain into the subsidence centre of $c$. $\mathrm{I} / 440$ over $7.5 \mathrm{~km}$. Thirdly, the great similarity of both exposures argues for their contemporary formation. Cvijic notes what are apparently recent lacustrine carbonates at and near the surface of the recent alluvium $(1908,251,256)$, elsewhere in the plain. This suggests that we might extend the slightly buried lake formation throughout the main plain. 


\section{IO. 7. Bintliff. THE PLAIN OF WESTERN MACEDONIA}

During the Pliocene period in Greece, many post-Alpine subsidence zones, due to irregular drainage outlets and contemporary high sea-levels, ponded up into extensive and calcic lakes, e.g. the Drama/Strimon basins, Central Greek depressions, Sparta/Megalopolis basins. Continuing subsidence and later deposition of colluvium and alluvium leaves these lacustrine formations preserved only at the basin rims, as with the Miocene-Pliocene sediments fringing the Macedonian Plain. In some larger basins, however, the Pleistocene overlay has been unable to swamp all the Pliocene beds, even in the zones of high depression, e.g. in the Sparta Plain (Bintliff 1975a).

The gentle slope we interpolated for the calcic silt in the Macedonian Plain argues against significant unconformities in the formation since deposition. Nevertheless, the Nikomedeia low knoll, rising a metre above the general plane of the formation, and the suggestion that pollen absence reflects subaerial weathering, points to limited weathering and reworking of this formation by the early Holocene. Since the major subsidence occurred from the Pliocene and continued through to the middle Pleistocene, it is unlikely that the lake surface preserved as the white silt predates the late Pleistocene.

By the early Holocene $\mathrm{Cr}_{4}$ date of $7270 \mathrm{bp}$, possibly c. 6400 B.c. in calendar years, the sea had encroached on this lake series, then apparently little altered from its state when it floored an active lake. The maximum Würm sea-level low could have caused the lake to dry up and its calcic formations to weather subaerially. Given the climatic scheme favoured by the writer (Bintliff $1975 \mathrm{~b}, 1976 \mathrm{~b}$ ) such a lake is feasible for early-to-middle Würm, with high rainfall and before maximum sea-level depression. The absence of overlying deposits until the Holocene alluviation is surprising, since c. 30,000 years elapsed between middle Würm and early Holocene, but the Sparta Basin provides a parallel. However, the freshness, purity and well-preserved surface of the silt might support a date closer to the earliest Holocene. (For high 'pluvial' lakes in Greece see Nicod 1963 ; Schmid 1965 ; Higgs et. al. 1967).

Recent alluvium above the white silt around the Nikomedeia tell, and throughout the upper plain, is arguably an historical formation (see below). Reconstructing, then, the 7 th millennium B.C. environment of the Plain, contemporary to Early Neolithic settlement, we find most of the plain proper consisting of lacustrine silts, open to the air, gently sloping into the Pella depression. In the depression centre $c .2 \mathrm{~m}$ of alluvium had accumulated. Sea-level was then $6-9 \mathrm{~m}$ below present.

In fig. 4 this data pinpoints the likely position of the contemporary shoreline; the coast probably lay 5.3. to $6.7 \mathrm{~km}$ from Nikomedeia. As for abandonment due to isolation of the tell by rising sea, in the 6 th millennium B.C., the coast would have been 5 to $6 \mathrm{~km}$ from the tell (interpolating at $c$. $1 \mathrm{~m}$ ocean rise per millennium).

It is noteworthy that any further contemporary alluvium above the white silt would merely raise the land area higher above sea-level, making the tell even more distant from the sea.

\section{Recent Alluviation in the West Macedonian Plain}

At the junction of hill-land and plain, one moves straight onto a recent alluvial surface typical for Greece, the Younger, or Historical, Alluvial Fill (Vita-Finzi 1969; Bintliff 1975b, 1976a). Strangely no authority mentioned hitherto deals in any detail with alluvial processes. Rodden's view echoes the general: 'The limited evidence suggests that the Nea Nikomedeia settlement was located near the coast, in a rich alluvial plain, as are the 'Thessalian early farming settlements' (1962, 288).

When Cousinery and Struck visited the region, the rivers Aliakmon and Axios were depositing a large body of sediment, a process causing their deltas to push out into the Thermaic Gulf. Since Classical sources suggested a smaller plain and a larger gulf, so that Pella was anciently a sea-port, it seemed only necessary to project backwards this process of alluviation to explain the formation of the enlarged modern plain.

Problematical, observing Struck's reconstruction maps (fig. 8), is the great growth in the plain 
occurring between 500 B.c. and I B.C., compared to the practical absence of an alluvial plain before that time. Surely rivers extended their deltas throughout preceding millennia? Oberhummer $(1937 ; 344-5)$ showed contradictions between ancient texts and these reconstructions: the Aliakmon river did not join the Loudias (Moglenitsa) when required, nor was the later shipway linking Pella to the sea allowed for.

Rodden, adopting the Struck sequence, explained the rapid changes of historic times as a natural result of sea-level rise since the Classical epoch (1964, 112). This was somehow linked to Struck's view, that the coalescence of major river deltas ponded up sediment behind natural dams. But why was this development not registered in the plain before $c .400$ B.c. (see below), despite demonstrable continual ocean rise, at the same rate, since the 7 th millennium B.c.? What is unique about the rooo

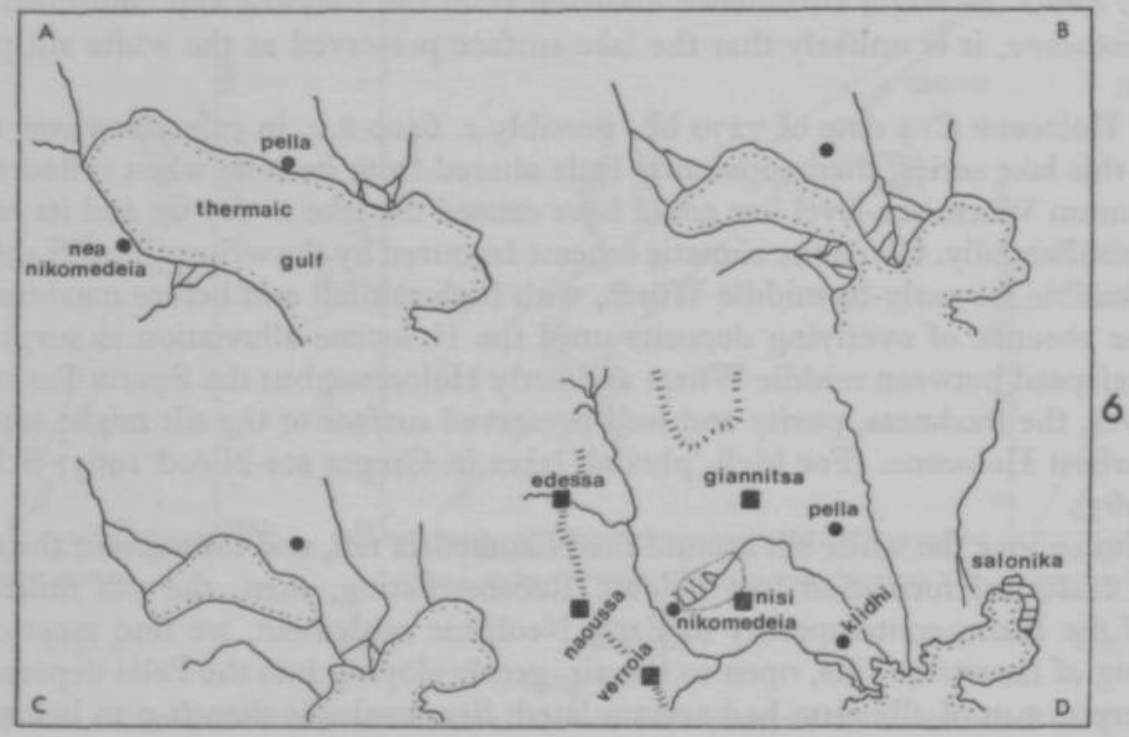

Fig. 6

Bottema's reconstructions of the growth of the Plain (based on Bottema r974). Key: $\mathrm{A}=$ about 8500 bp. ( $\mathrm{Cr}_{14}$ ); $\mathrm{B}=$ about $200-0$ B.C.; C = 500 A.D.; D = recent situation, dotted line marks Lake Giannitsa around I900 A.D.

years between Classical and early Medieval times? For Struck's data demonstrates clearly that the plain was largely created between those dates, since $c .500$ A.D. advancing little on the sea (cf. fig. 8).

Figure 6 shows Bottema's reconstructions, heavily reliant on Struck. Prof. N. Hammond discusses the plain's evolution in some detail $(1972,141-75)$. His interpretation partly coincides with that of the author, though his maps contradict his text, and each other ( $c f$. his maps 12 and 15 ), and he cannot account for the rapid plain infill of historic times (see fig. 7).

Let us first consider the available historical evidence for the retreat of the Gulf and the advance of the plain. These sources are usefully catalogued by Struck, Oberhummer, and also Edson (1955).

In the Histories of Herodotus, composed c. 450-425 B.c., we are expressly told $(7,123)$ that the cities of Pella and Ichnai occupy a narrow stretch of land along the sea. Pella is positively identified, Ichnai is usually placed close by to the east (Struck $1908,2,93$; Hammond $1972,15^{2}$ ). A river Ludias unites with the river Aliakmon before reaching the sea $(7,127)$ and the river Echeidorus enters the sea alongside the Axios swamp $(7,124)$. The Aliakmon is clearly the large river of that name entering the plain from the southwest, and the Echeidorus is without doubt the Gallikos river in the northeast plain; the Axios retains its name, entering from the north-centre. The 'Ludias', now the name of a 


\section{I0. 7 . Bintliff. THE PLAIN OF WESTERN MACEDONIA}

large drainage canal emanating from the former centre of the Giannitsa Lake, is recorded in antiquity as a river entering the plain from the Almopias Basin, clearly the Moglenitsa. In Ptol. 3, 13, 24, Almopia has three cities, one being Europus. In Pliny, Nat. Hist. 4, 34, Europus lies on the river Ludias. He actually says 'Roedias', a variant term designating the upper Ludias. The significance of upper and lower Ludias will emerge later. Finally, ancient Edessa lay by the Ludias, a city indentified beside its descendant (Schmidt 1893, 944).

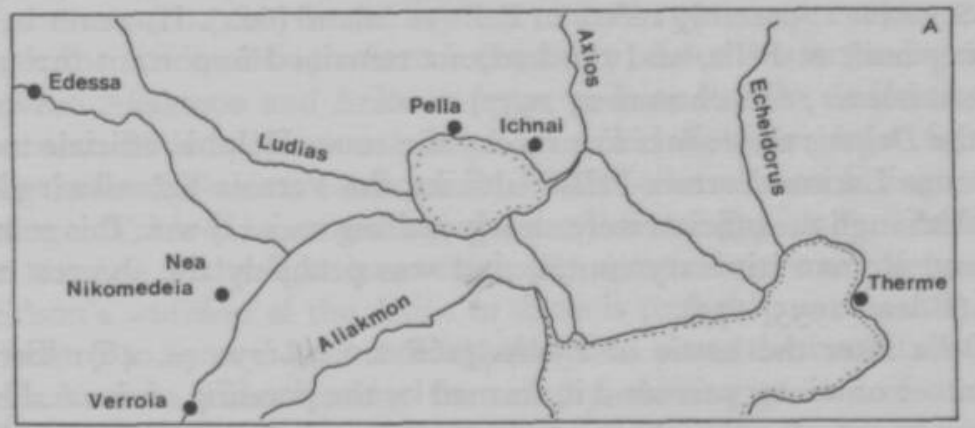

7

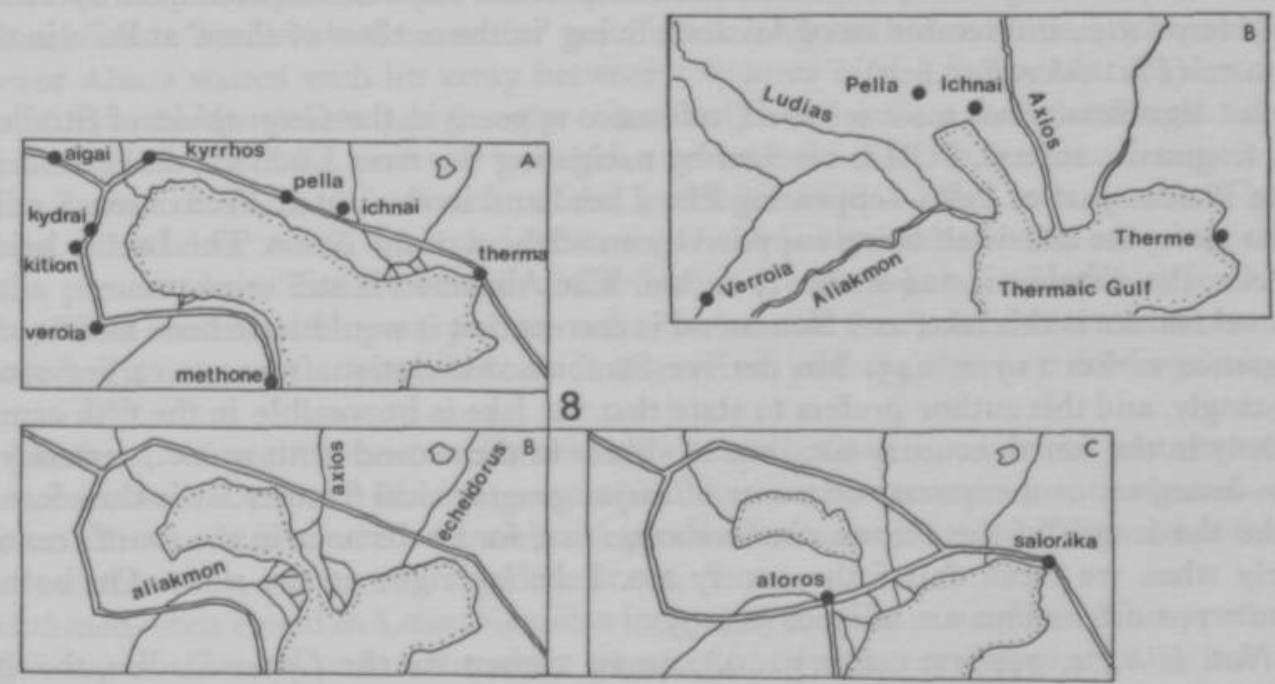

Fig. 7

Hammond's reconstructions of the growth of the Plain (based on Hammond 1972). Key: $A=$ around 600-450 B.C.; $\mathrm{B}=$ as in the Strabo description, here dated to around 356 B.C.

Fig. 8

Struck's reconstructions of the growth of the Macedonian Plain (based on Struck, 1908 and Casson, 1926). Key: $A=$ to end of the 5 th. century B.C.; $B=4$ th to rst. centuries B.C.; C $=1$ st. century A.D. to 500 A.D.

Only Hammond accommodates these details into a map of the Classical plain (fig. $7 \mathrm{~b}$ ), with Oberhummer realizing correctly that the confluence of Aliakmon and Ludias must mean that the area of contemporary Gulf was smaller than imagined, and that the Aliakmon flowed north-east rather than eastwards as today.

In Thucydides' History, late fifth century B.c., a description of Macedonian mountain peoples concludes 'coming down from here to Pella and the sea' $(2,99-100)$, confirming Herodotus. It is 
significant that, in Thucydides, when the Athenians marched from Pydna to Potidaea, a route necessarily traversing the Macedonian plain, they went inland from Pydna to Verroia, as if to encircle the plain, neglecting the obvious presentday route around the coast and across the plain (r, 6r; cf. fig. $\mathrm{r}$ ).

By Pseudo-Scylax (probably mid fourth century B.c.), Pella's status has altered (66). The sailor from the south is directed to the Aliakmon estuary, then to the river Ludias (now separated from Aliakmon). Pella is reached sailing up the Ludias on a shipway ('anaplous'). The probably contemporary Pseudo-Scymnus apparently refers to Pella as inland (624). However in 288 B.c. a fleet of giant ships was being built at Pella, and the harbour remained important throughout Hellenistic times (Plutarch, Demosthenes; Oberhummer, 1937).

In I90-180 B.c. the Delphic theorodaki lists record the route Delphic officials took from Thessaly to Thessalonika. It runs Larissa-Verroia-Pella-Salonika, the Verroia-Salonika leg being $c .124 \mathrm{~km}$ or c. 84 Roman miles. Although the officials were clearly visiting major towns, this route closely parallels the Athenian one and Roman itinerary routes, and was probably the shortest route possible till Late Roman times (Edson 1955, 173).

Livy describes Pella after the battle of Pydna (г68 в.c.; Livy: 44, 46): 'Swamps of a depth impenetrable in summer or winter surround it, formed by the ponding of rivers. Phacus projects like an island from the swamp itself, where it comes nearest the city'. These swamps may be the Axios swamp of Herodotus, and remind us of Aristotle living 'in the outflow of slime' at Pella in the fourth century B.c. (Plu. Moralia, 603).

The most significant, but most misused, reference appears in the Geographies of Strabo, around I B.C. (7, fragments 20, 22). Pella is reached by navigating the river Ludias to Lake Ludias; in the lake is the Phacus part of Pella-appearing like a headland in the water. From Lake Ludias issues the Ludias river, the lake itself being supplied by an offshoot of the Axios. The Ludias being navigable to Pella, the distance is 120 stadia, c. $22 \mathrm{~km}$. The Aliakmon is still separate.

The novel feature is this lake, and Hammond is correct that it would have been mentioned before if in existence earlier (1972, 145) He derives Strabo's description from an earlier source, but unconvincingly, and this author prefers to state that the lake is impossible in the fifth century B.C., very unlikely in the fourth century B.C., not too likely in the second century B.C., certainly attested by $\mathbf{I}$ B.c.-based on contemporary accounts of major geographical features. It is therefore unjustified to take the length of the shipway in Strabo, $22 \mathrm{~km}$, for its distance in the fourth century B.C., particularly when we recall that fifth century B.c. Pella lay right on the coast. On both counts, Hammond's reconstructions are suspect (fig. 7).

Pliny (Nat. Hist., 4, 34; first century A.D.), uses a variant for the Upper Ludias, the 'Roedias'; this doubtless refers to the Moglenitsa river, which for obvious geographical reasons continued to flow from inland into the depression core before Pella, now occupied by lake Ludias. The 'Ludias' now became the outflow of the lake to the sea, rather like its modern descendant.

The Antonine Itinerary gives the route between Thessaly and Thessalonika as running PydnaVerroia-Pella-Salonika; the Verroia-Salonika leg is $c .76 \mathrm{~km}$ (51 Roman miles). This is shorter than the Delphic town by town route, but on calculations the road still skirted the central plain, joining the Via Egnatia west of, and near to, Pella. These calculations are by C. Edson (1955, 175), dating the Antonine Itinerary to the period of Caracalla (2I I-2I 7 A.D.). He argues that Thucydides and the Delphic lists also indicate basically the same route around the plain, whose waterlogged, miry soils rule out a shorter route around the coast northwards from Pydna. Pydna to Verroia, then to Salonika, is quite a detour unless one is encircling the far west of the plain (cf. fig. 2).

The Peutinger Table, also late Imperial, supports the Antonine, giving a route Pydna-VerroiaPella-Salonika, and 57 Roman miles for the Verroia-Salonika leg. But Edson (1955, 178) uncovers another, shorter, route, in a confused version within the Peutinger Table. This route comes from 


\section{0. f. Bintliff. THE PLAN OF WESTERN MACEDONIA}

Pydna, around the coast, bypassing Verroia and Pella and running straight across the plain to Salonika. Edson dates this new road around 300 A.D. when military insecurity necessitated a feat of engineering, bridging with a fast line of communications the hitherto impassable central plain.

Supporting evidence is available. Firstly, around 300 A.D. Verroia, hitherto prosperous, suffers a drastic decline. Edessa, in the northwest plain, remains important, because it was still on the major Via Egnatia (Edson 1955, r8o). Pella, also on the Egnatian Way, though absent from the Bishops' Lists, was still significant around the time of Pellaeus, a poet probably born at Pella when his father was Prefect of Macedonia (late fourth century A.D.; Isbell 1971, 242, 297).

Secondly, there is the Klidhi Bridge. Struck $(1908,17)$ dates this imposing monument near the present coast, between Aliakmon and Axios mouths, as Late Roman. It ied Struck to suggest that by $c .500$ A.D. the main road directly crossed the plain instead of skirting it (cf. fig. 8). Re-examination of the evidence for the bridge's date confirms Struck, its construction fitting neatly with the short route of the Peutinger Table (Hammond 1972, 161; Edson 1955, 178). The Bridge is landlocked today, $5 \mathrm{~km}$ from the sea, and might have originally spanned several rivers, e.g. Aliakmon and Ludias (lower). Edson's addition of the Axios to these is probably not feasible.

The Bridge is located to serve a road entering the plain along the coast from Pydna, rather than the inland route via Verroia. Thus far onto the marshy, shifting ground of the deltas, there seems little doubt that Roman engineers were able to push the road right across the lower plain to Salonika.

Hammond cites a Medieval reference for use of both long and short routes (1972, 162). In 1078 the Emperor Alexis waited with his army between two arms of the Axios, near Chalastra, but his enemies did not take the direct route (i.e. the coast road) but came by the inland road. Chalastra is somewhere southeast of Pella, and the two Axios arms could refer to continued supply from the Axios, via a western branch, of freshwater to the Ludias/Giannitsa Lake, as in Strabo. The eastern, main course of the river would flow straight to the sea. A bridge buried amid alluvium near Pella, west of the present Axios bed, is Medieval for Struck (1908, 12), later Medieval for Hammond (1972, 16r). This evidences temporary westward movement of the Axios, known in recent centuries (Struck 1908,5 ), or marks a lesser branch of that river, perhaps that one feeding Lake Ludias/ Giannitsa.

From Medieval times till recent reclamation and canalisation, a consistent picture emerges-a vast level plain, with a surface of moist recent alluvium, criss-crossed by shifting and seasonally violent rivers. The lower level of the Giannitsa depression encouraged the shifting rivers temporarily to course into this zone, rather than the distant sea.

The Aliakmon often ended in Lake Giannitsa instead of the Thermaic Gulf. This process created an enlarged lake $c$. 1600 A.D.; when the water retreated, a new course was taken. One branch joined the Ludias, another branch discharged into Lake Giannitsa. Finally the river was constrained into its old bed by a dam, which broke in the nineteenth century A.D. A forest and 200 houses disappeared and an enlarged lake was created; another dike was built (Bottema 1974, 75).

Cousinery $(1831,61-66)$ notes a village formerly west of the Axios,now on its east. He cites inundated villages, bridges, corn magazines buried in alluvium within memory. We read that the Aliakmon was recently canalised, flowing hitherto mainly into the Ludias stream.

More recently (but before the I920s) the Axios and Ludias rivers discharged together into the Gulf, but dikes were built; and now the Axios discharges three kilometres east of the Ludias (Bottema 1974, 76). Struck's 1908 map of the plain shows the situation before this separation (fig. ro f).

Note on this map that Lake Giannitsa/Ludias follows the subsidence axis, although a marshy zone extends southwesterly towards Verroia. This Lake was then $3 \mathrm{~m}$ deep, it surface $4 \mathrm{~m}$ a.s.1. It normally covered $5 \mathrm{sq}$. km., but at high water twice as much was submerged. It lay within a marshy zone c. $90 \mathrm{sq} . \mathrm{km}$ in extent, mainly spread to the south-west (Struck, 1908, 23). The Admiralty 
Handbook (1945, fig. 24, p. I15) incorrectly shows the Lake covering most of the land assigned to marsh by Struck and other contemporary commentators. Struck's limits on the Lake agree exactly with Cvijic ( 1908$)$ and Cousinery (183r). Partly because of this inaccurately 'enlarged' lake, almost reaching Nikomedeia, that tell was usually viewed as a former lakeside or marine community, although this is not a probable locational environment for prehistoric and Classical times, or the last $\mathrm{x} 50$ years.

Let us now consider evidence for alluviation, particularly affecting the inner western plain, above ocean throughout the Holocene.

In Homer a goddess once passes through this region (Iliad, 14, 226): "leaving Olympus Hera set foot on Pieria and then on Emathia, as to Thrace. . . Emathia refers in later antiquity to the Macedonian plain west of the Axios. Strabo records that this district now called Bottiaeis, was formally called Emathia ( 7 , fragment II), and during Roman times the name was readopted. Hammond comments 'Emathia "the sandy place" suits the plain of Lower Macedonia' (1972, 295), a baffling statement, for the plain is composed, superficially, of alluvial silts and peats, heavily waterlogged. In winter and spring vehicles can hardly traverse much of the bottomland. Its prereclamation condition was considerably worse.

There are two possibilities: either 'the sandy place' refers to alluvial sands, or to the underlying lacustrine series. The alluvium observable throughout the plain, both surface and in section is always clayey silt, deposited by ponding and meandering streams.

The lacustrine silts are pure calcium carbonate, and with a high watertable exhibit characteristic water-retention, swelling and giving a superficially 'clayey' appearance. For this reason both Rodden and Bottema label the formation as a clay, though it occupies more accurately the sandy end of silt. The alluvial silts would also be less muddy if the watertable lowered drastically, though they are more naturally clayey in particle size. The alluvium in the plain is characteristic for poorly established rivers, shifting beds unpredictably, creating perennial pools and marshes and maintaining a high watertable. This situation continues in slightly modified form today, with a high watertable and permanent openwater channels throughout the plain. In conclusion, the alluvial silt has always been a swampy mud.

In contrast, the lacustrine series lay open to the air for a considerable time, well above the watertable. When the ocean first transgresses this formation, c. $7270 \mathrm{bc}$, the only part of the plain underwater is clearly the depression centre, the area around the core-site and extending towards the southeast. A few millennia before, when ocean levels were lower, all the western plain would have been dry land, and it was then that subaerial weathering removed pollen and other organic traces from the white silts, carving out low rises such as the Nikomedeia hillock. Ponding up on the lacustrine formation only occurs considerably later, in historic times, when sea-level was higher and pollen profiles suggest extensive freshwater lakes. Until then, the white silts constituted tremendously fertile, well-drained soil, light to work, retentive of nitrogen and seasonal rainwater through the long dry season, a typical rendsina soil as favoured by prehistoric farmers throughout Greece. Hence an apt description of the western plain as 'the sandy place'. For comparable use of this adjective for soft lacustrine/marine sediments inland, consider the Homeric epithet for Nestor's palace in Messenia - 'sandy Pylos'. Critics have argued that the palace must lie by Pylos Bay, rather than on Englianos hill, inland (Kraft 1972, 64). But the Englianos palace occupies fertile hilland of marine silts.

Archaeology provides clues for the dating of subsequent alluviation. Firstly, at Nea Nikomedeia (fig. 3), the white silt hillock forms an island amid alluvium; the alluvium overlies the silt in places (e.g., the nearby drainage ditch), elsewhere (e.g. the prehistoric ditch cleared by the excavators), the alluvium overlies prehistoric levels-which overlie the white silt. Almost certainly after Late Neolithic folk abandoned the tell, the ditch they had dug began to silt up (held by Rodden to be a natural weathering, rather than human refuse dumping). Its silting is characteristically natural 


\section{IO. $\mathcal{f}$. Bintliff. THE PLAIN OF WESTERN MACEDONIA}

subaerial infill, with gradual interpenetration of wash from the ditch sides. Weathering of the tell also contributed fill material. These deposits are sealed by horizontal bands of calcic crust, at ditch mouth level, and created after silting had entirely infilled the depression. Above the crusts lies the recent alluvium. (The writer is grateful to Prof. Rodden for invaluable assistance in interpreting deposits within the tell.)

Both alluvium and calcic crusts indicate a new environment, with high streams, ponding of waters - probably into full summer-and a notable bedload for rivercourses. The inception of this novel regime should postdate the Late Neolithic. There are traces of reworking of the ditch fill by ponding waters, while the crust and alluvium represent an obvious disconformity with underlying deposits. Any later time till the highest locally recorded water levels is possible for commencement of the new sedimentary environment.

In 1964 , Greek archaeologists report (Deltion $1964, B_{3}, 359$ ): 'In opening up irrigation channels within the former Giannitsa Lake... ancient pieces of stone and marble of large dimensions were uncovered concentrated $c .750 \mathrm{~m}$ north of the road from Salonika to Verroia ... near Schoinas village. The stones ... are of the best Macedonian years - some fine edifice or sanctuary.... The fragments were torn and disturbed from the mud by mechanical diggers, leaving it unclear ... whether we have an in situ monument or whether ... various materials were concentrated or washed here by unknown means'. One column was apparently inscribed in Latin.

We have here a common phenomenon in Greece (Bintliff $1975^{\mathrm{b}}$ ), ancient monuments buried and dislodged by post-Roman riverine activity. The dimensions of the blocks, and their possible attribution to a sanctuary, suggests that the former Giannitsa lake has seen considerable changes since Roman times, involving notable rises in alluvial sediment and watertable.

In $r_{3} 1$ Cousinery cites frequent sightings, in summer, of submerged ruins totally buried in muds on the edge of Giannitsa Lake $\left(18_{3} 1,65\right)$. In winter, the rainy season, a higher watertable would have obscured them. These ruins should be substantial and stone-built, to survive such conditions and be recognisable as former buildings. It is unlikely that they pre-date the historic period in this region. (Cf. similar alluvial swampings of Medieval and later date in Cousinery [1831, $66]$ and Struck $[1908,12]$.)

Finally, an area once open sea, the Classical period environment south of Pella, was apparently impassable to ancient engineering throughout Hellenistic and early Roman times (when it had become a large and marshy lake) but in Late Roman and Byzantine times a major road, with a bridge, ran directly through it.

\section{The Historical Alluviation of Vita-Finzi}

In Vita-Finzi's dual Mediterranean alluviation sequence (Ice Age then Medieval) these Older and Younger Fills were deposited throughout the valleys and plains as a result of climatic change, which created precipitation regimes moister than today's 'Mediterranean' pattern (Vita-Finzi 1969; Bintliff $1975^{b}, 1976 a$ and $\left.b\right)$.

Vita-Finzi distinguishes between the sedimentation system operating from $c$. 10,000 B.c. to Late Roman times, and during the last few centuries, in comparison to that operating during the period intervening, the Late Roman and Medieval era. The 'Mediterranean' regime witnessed limited alluviation confined to rivermouths and closed depressions, but the latter 'moist phase' regime saw little 'deltaic fill' but massive aggradation along rivercourses and throughout the plains.

In a coastal plain we expect an extension of deltas at major rivermouths, between 10,000 B.C. and early Roman times. The coastline would advance wherever larger rivercourses deposited their bedloads. In the plain hinterland we predict no significant alluvial deposition throughout this period. But during Late Roman and Byzantine times, coastal progradation would be restricted, and large masses of sediment would swamp the hinterland. In recent centuries the former regime would 
return, with coastal progradation and a cessation of plain aggradation. Because world sea-levels rose rapidly until 8,000 years ago, deltaic extension was severely hampered; furthermore, the steep shores of the glacial coast (roo metres below present levels) meant that coastal sedimentation had first to infill deep inshore areas before a subaerial delta could prolong itself above the waves. After c. 8000 bp (Bintliff 1975a) a slower ocean rise and accumulating inshore sediments permitted deltas to prograde.

This prediction fits admirably with observed details of the W. Macedonian Plain and its Holocene development. We can also introduce Bottema's reconstructions (1974) of hydrology and vegetation in this period.

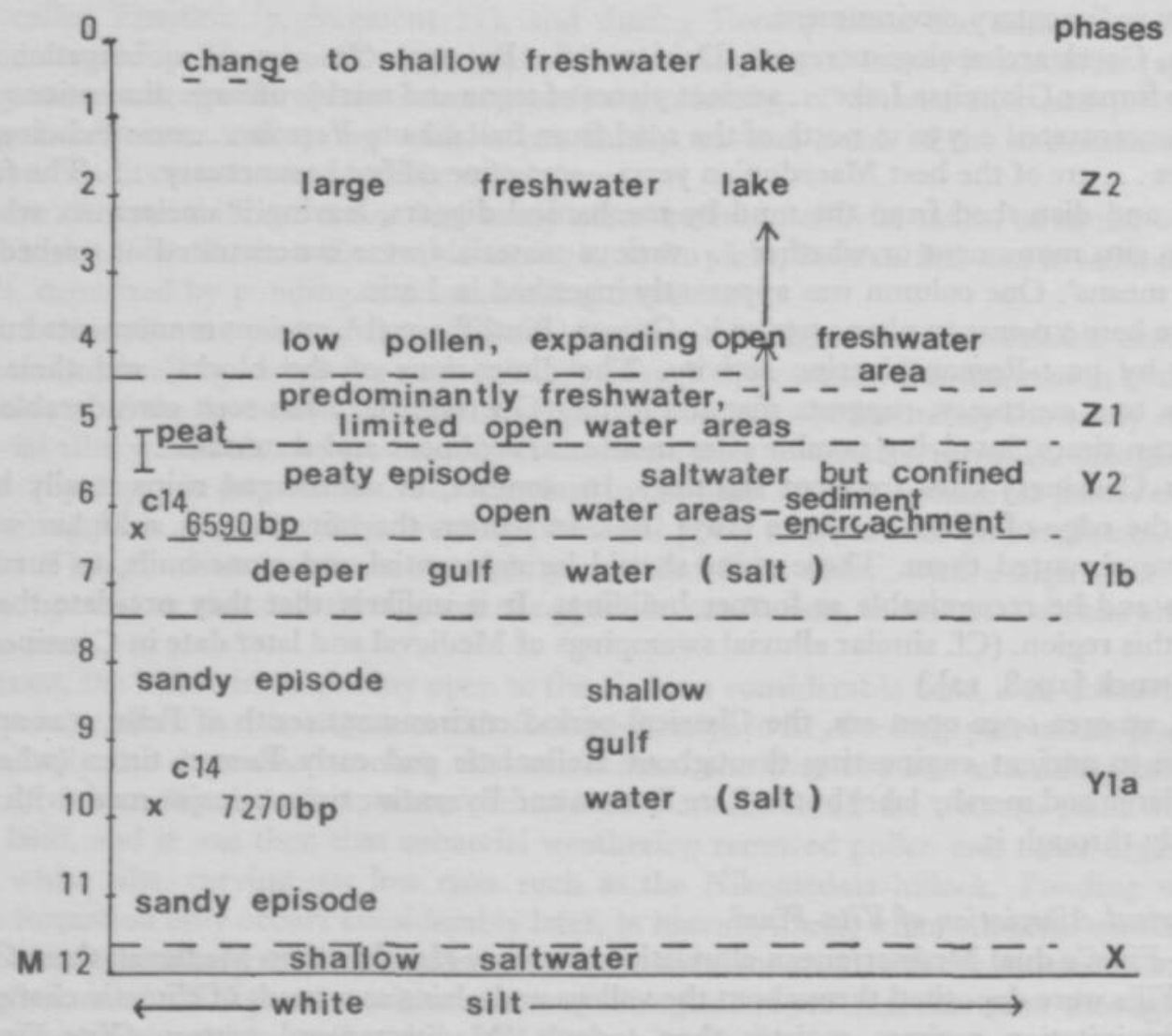

Fig. 9

The sedimentary sequence in the Giannitsa core (based on Bottema r974). Depths in metres; top of core is approximately I metre above present sea-level. Phases are vegetational divisions, characterised as follows: $\mathrm{X}=$ deciduous woods and swampy forests; $\mathrm{Y}_{\mathrm{ra}}=$ as in $\mathrm{X}$ but increased proportion of swamp forest; $\mathrm{Y}_{\mathrm{rb}}=$ notable decline in plain forest, expecially swamp variety; $\mathrm{Y}_{2}=$ return to conditions of $\mathrm{Y}_{1 a} ; \mathrm{Z}_{1}=$ as $\mathrm{Y}_{2} ; \mathrm{Z}_{2}=$ as $\mathrm{X}$ and $\mathrm{Y}$ ra with occasional clearance phases possibly due to farming and herding.

Figure 9 shows major features of the Giannitsa core environment. We begin, in early Holocene, with a shallow marine environment; the sea has recovered sufficiently from its Würm low to occupy this lowest area with shallow Gulf-water (Phase X). In Yla, during which Nikomedeia was settled, shallow sea continues, although a river introduces seasonal volumes of freshwater nearby; since later the Aliakmon is seen gradually moving from northeasterly to southeasterly flow, either this stream, 


\section{7. Bintliff. THE PLAIN OF WESTERN MACEDONIA}

or the Ludias/Moglenitsa is responsible. Indeed, in the Herodotean description of the mid-fifth century в.c. situation, these two rivers probably flowed together close to the core-site. Contemporary ocean depth at the coring, and the probable extent of the Gulf were noted earlier (figs. 4, 10).

In YIB Bottema claims a maximum extent for the Thermaic Gulf; at the core-site, limited local flora and a decline in higher vegetation assigned to the plain proper suggest that saltwater transgression has reduced the area where such plants could flourish; the saltwater above the coring is appreciably deeper. At this phase Bottema proposes necessary abandonment of the Nikomedeia site; the tell actually stood well above the ocean at this time, amid extensive dry, and fertile marls.

After this phase, the sea was unable to encroach further, being continually pushed back by prograding deltas. However, continuing sea-level rise elevated the freshwater watertable: the deepest hollow-the core-site zone and the trench running by Pella-was gradually filled by a lake, ultimately cut off from saltwater influence. Only at this last stage when the lake-level was $4 \mathrm{~m}$ or more above presentday ocean, would the Nikomedeia locality have succumbed to waterlogging.

These events are traced from the core: in $\mathrm{Y}_{2}$ the saltwater environment becomes permeated by freshwater influences, until the core-site witnesses only freshwater influence. Most of this phase consists of peat, first saltmarsh, increasingly freshwater peatmarsh. A $\mathrm{Cr}_{4}$ date from early on is $6590 \mathrm{bp}$. In the succeeding phase, $\mathrm{Zr}$, freshwater marsh and peat continue to be significant, but towards the end an open freshwater area forms, culminating in a large freshwater lake in $Z_{2}$. Only in uppermost $Z_{2}$ does this lake shrink in extent and depth. Bottema interprets the $Z_{2}$ situation as that recorded by Struck in 1908 . The late shrinking of the Giannitsa Lake surely refers to the difference between recent centuries, when the Lake was frequently fed by the major rivers Aliakmon and Axios, and the 1908 situation, when in Struck's maps, none of the main rivers directly feeds the lake.

Though lacking $\mathrm{C}_{14}$ dates from the upper half of the core, we can interpolate from history. The $\mathrm{Z}_{2}$ situation, before the final 1908 phase with its diminished lake, reflects the general picture of later antique references; therefore upper $\mathrm{Z}_{\mathrm{I}}$ is unlikely to predate Hellenistic times.

The area later occupied by Lake Giannitsa is chiefly the subsidence trench before Pella. In the fifth century B.C. this was certainly open sea, but during following centuries it became gradually cut off by deltaic sedimentation, stemming from Axios and Aliakmon on either side. Still it maintained free contact with the sea via a wide estuarine passage, the Ludias shipway. As yet, no mention of Lake Ludias. Only in Strabo will river and lake make their appearance, but after Strabo the Lake was fairly certainly existing primarily in its 1908 location until recent drainage work. The earliest occasion in Bottema's core when a predominantly freshwater lake filled the Pella/Giannitsa depression is uppermost $\mathrm{Z}_{\mathrm{r}}$, and from the core data this lake remained little altered till very recent times.

One long-term Holocene development is a conflict between deltaic sedimentation and a steadily rising sea-level. In the early core-record the sea gains, for reasons noted above, but the middle and upper core undoubtedly registers successful encroachment of alluvial sediments on former Gulf territory. Before sea-level began to approach present level, rivers draining into the plain were attracted into the Pella subsidence trench rather than the receding Gulf. As this depression filled with alluvium it ceased to represent a natural stream base-level; furthermore, ocean rise eliminated the gross differential between the depression and its immediate surrounding watertable. As a result, the main rivers adapted their courses to the most immediate route to the open sea. Hence the shift of the Aliakmon from the depression, down towards the main Gulf. The Aliakmon and Axios frequently reverted to flowing into the depression area, largely because alluvial blocking raised the new lake several metres above sea level, so that once more the depression offered an alternative baselevel for the major streams.

The difference between riverine sedimentation in the deltaic and historical alluviation phases, is the geomorphological function being served. In the former phase, streams are cutting down steeply- 
graded courses to a much flatter longitudinal profile, assisting this process by creating long, low estuarine coastal formations-so that material removed by upstream downcutting is not deposited in a fashion that steepens the river profile angle. This sedimentation will be of little depth above sea level and extensive only at the final base-level-open sea. Rivers naturally shift courses under this regime, otherwise their accumulated deltas would elevate base-level and set off a steepening of the upstream course. Such delta sediments being extensive but very little above sea-level, a rapidly rising ocean frequently swamps them until a slower eustatic regime allows deltas to advance at a greater pace.

In contrast, the alluviation phase of medieval times reflects a greater body of sediment than streams can cope with. They must steepen profile to avoid congestion and loss of transporting efficiency. They thus dispose of surplus sediment and also bring gravity to aid their competence in sediment transport. Streams do this by building up alluvial floors along their courses, except at the coast.

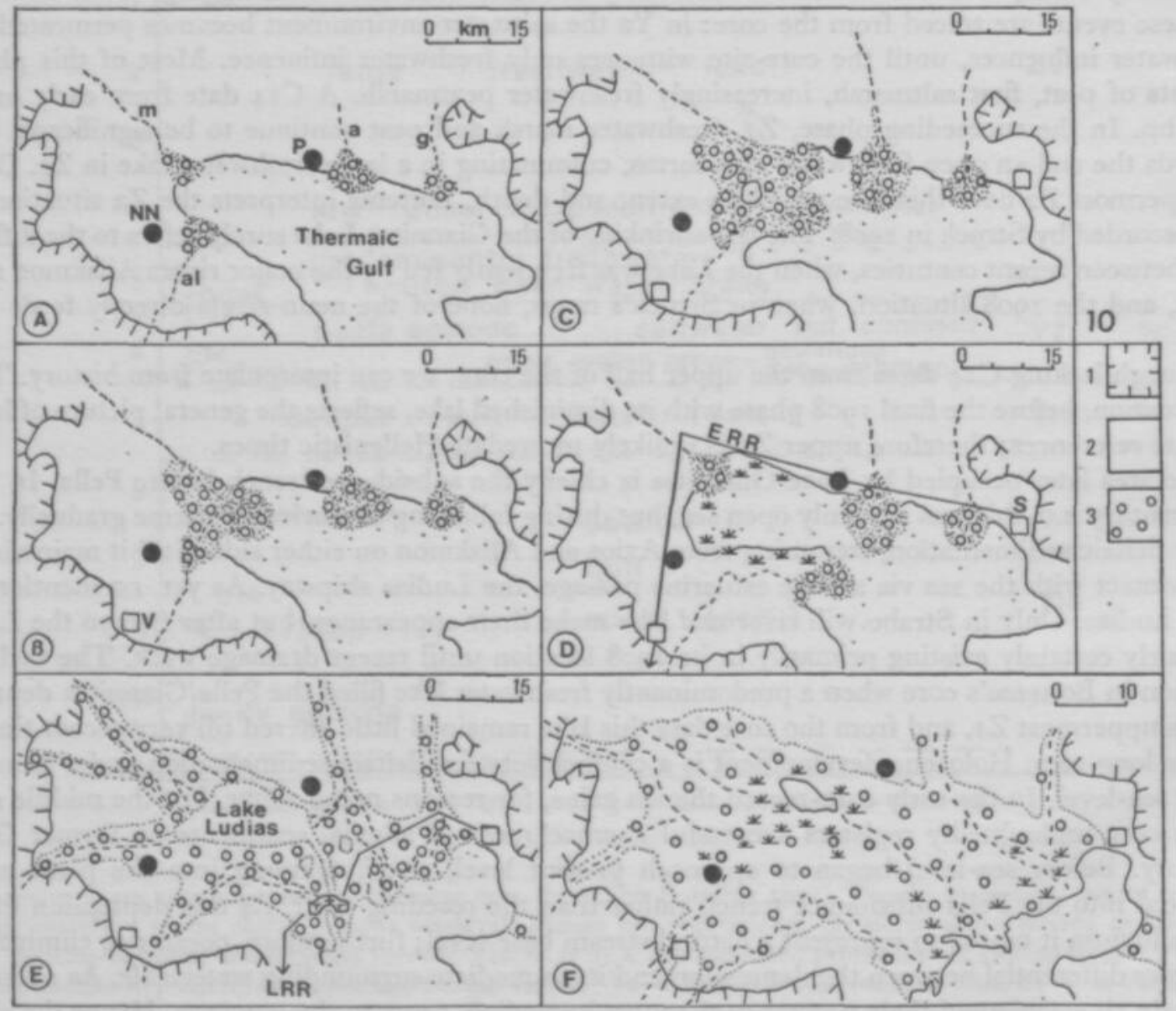

Fig. ro

The author's revised reconstructions of the growth of the Plain. Key: A = early prehistoric period; $\mathrm{B}=$ fifth century B.C.; C = fourth century B.C.; $\mathrm{D}=$ around O B.C./A.D.: $\mathrm{E}=$ Late Roman period, around 500 A.D.; $F=1908$ A.D. $x=$ Cristalline limestone upland; $z=$ Tertiary and Quaternary lacustrine marls, sands, silts and travertines; $3 \doteq$ Younger 'Historic' Alluvial Fill and Holocene deltaic fill. NN $=$ Nea Nikomedeia; $\mathrm{P}=$ Pella; $\mathbf{S}=$ Salonika; $\mathrm{V}=$ Verroia $; \mathrm{m}=$ Moglenitsa river $:$ al $=$ Aliakmon river; $\mathbf{a}=$ Axios river; $\mathbf{g}=$ Gallikos river; ERR = Early Roman Road; LRR = Late Roman Road. 


\section{IO. $\mathcal{f}$. Bintliff. THE PLAIN OF WESTERN MACEDONIA}

Any prolongation of deltaic sediment further complicates the stream's task and we predict therefore minimal coastal infill during the historical alluviation.

Figure ro illustrates the writer's reconstructions of the Holocene development of the Macedonian Plain.

In roa, the sixth millennium bc situation, a large area of the plain is part of the Thermaic Gulf. The extent of the inlet is calculated from core data, natural limits of the axial depression, and the late silting up of Pella. Only limited amounts of alluvium, almost entirely deltaic, lie at major rivermouths. This is to be expected since the rapid eustatic ocean rise phase had only recently been in operation, and we infer the amount of alluvium from the core, from extrapolation of the early historical situation and from the absence of alluvium at Nikomedeia. The core-site lay just inside the ocean, not far from the deltas, hence the freshwater elements in this part of the core. The predominance of the lacustrine silt, above the ocean, in the western plain, is reflected in the later regional name of 'Emathia', a term appropriate till Roman times. The direction of the Ludias/Moglenitsa and Aliakmon is geologically conditioned and supported by the first historical reference, Herodotus. The alluvial sediments continue to lack depth above sea, therefore marshy and valued only for game and grazing, until Late Roman times.
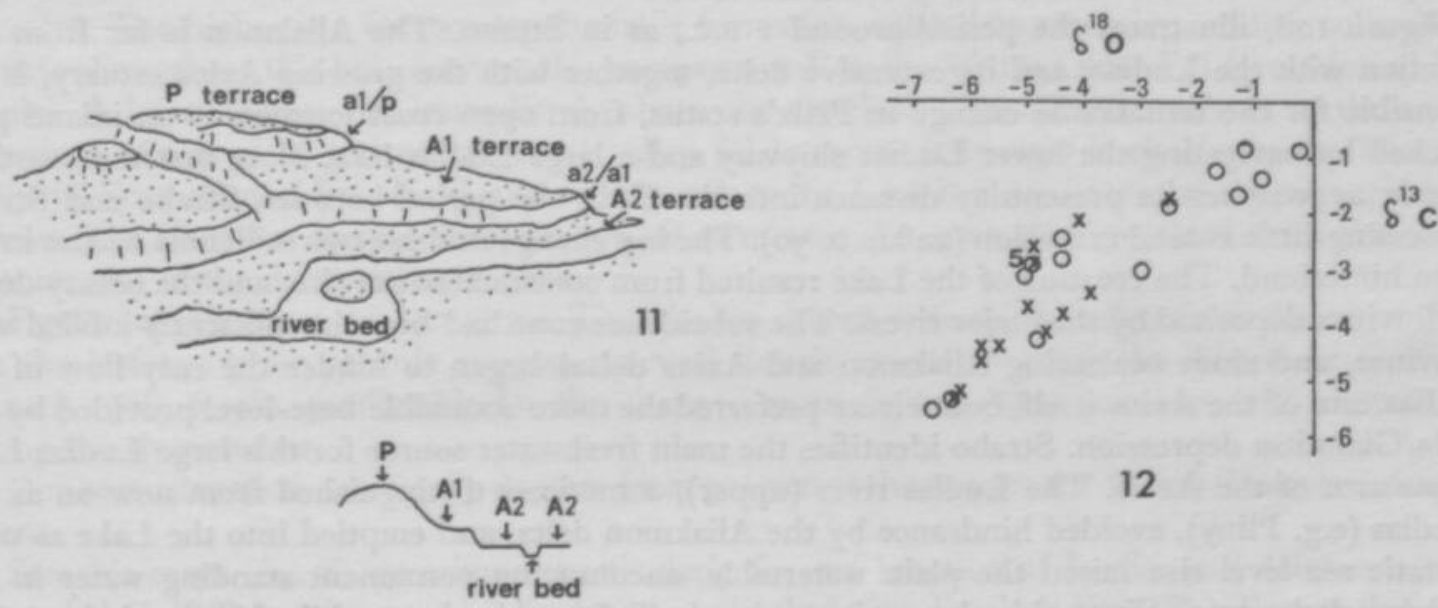

12

Fig. II

Diagram and cross-section of recent sediments in a valley of the hill-land adjacent to the Macedonian plain (after Mercier 1973). Key: P = Pliocene (?) terrace; $\mathrm{A} 1=$ Pleistocene terrace; $\mathrm{A} 2=$ Holocene terrace.

Fig. 12

Oxygen isotope analysis of Cardium shells from Nikomedeia (after Shackleton r970). Isotope readings in parts per thousand. Thirteen sample shells and their season of capture are indicated by crosses; sequential growth implements of one shell (number 5 on the same diagram) marked by open circles. The spectrum from -2 to 0 represents summer, the range -7 downwards to -3 represents deep winter succeeded by spring and autumn.

Figure rob shows the probable situation in the time of Herodotus and Thucydides. The two western rivers unite briefly before the sea, their confluence relating to the axial depression's function as a base-level for these streams. Their united deltaic sediments on the west, and the Axios delta on the east, account for the description of Pella and nearby Ichnai as on a 'narrow stretch of land along the sea' and the marshy Axios delta near Pella accounts for the earlier name 'Bounomos', 'oxenland'. Compare also Aristotle living 'in the outflow of slime' at Pella. It is clear that we can put a limit on 


\section{THE PREHISTORIC SOCIETY}

the Aliakmon/Axios/Ludias deltas, by keeping Pella and Ichnai open to the Gulf, and bringing together the two western rivers in a geologically acceptable zone, i.e. the subsidence lowland.

The appearance of the Lake came, fairly certainly, some centuries after this phase, Bottema's upper $\mathrm{Z}_{\mathrm{r}}$. So the period between open ocean at the core-site and at Pella, and the open lake of freshwater at those locations, must correspond to the last few centuries B.c. and section $\mathrm{Z}_{\mathrm{I}}$, lower and middle parts. On this basis we can establish agreement between the core and historical records. For the former demonstrates a transition from shallow sea and saltmarsh, to freshwater marsh ( $\left.\mathrm{Y}_{2}\right)$, to open freshwater lake $\left(\mathrm{Z}_{1}\right)$, to a large freshwater lake $\left(\mathrm{Z}_{2}\right)$. History records a transition from open ocean and saltmarsh (fifth century B.c.) to freshwater marsh and smallish freshwater lake and/or estuary, i.e. the 'shipway' (fourth century B.c. onwards), to large freshwater lake (c. I B.c. onwards)Lake Ludias/Giannitsa.

In Figure IOc, the fourth century B.C., continual accretion of deltaic sediment has narrowed the Pella ocean outlet to a wide shipway, dominated by concentrated freshwater flow from the closely adjacent three great rivers. The separation of Ludias and Aliakmon arguably arose from southward migration of the latter; we saw why this could occur, we know historically that it had by now, and we interpolate the Aliakmon's course from its previous junction with the Ludias and the later Strabo picture. Since the deltaic sediment remained shallow, it is possible that open freshwater largely occupied areas between the formerly confluent rivers.

Figure rod, illustrates the period around I B.C., as in Strabo. The Aliakmon is far from any junction with the Ludias, and its extensive delta, together with the growing Axios estuary, is responsible for the remarkable change in Pella's status, from open coast location to an inland port reached by navigating the lower Ludias shipway and a large Ludias lake. Note that the coastline already approaches its presentday distance into the Gulf, the period between Strabo and Struck witnessing little coastal extension ( $22 \mathrm{~km}$ to 30 ). The big change in these two millennia occurs in the plain hinterland. The creation of the Lake resulted from continual ocean rise, and the scanty depth of alluvium deposited by the major rivers. The subsidence zone had been insufficiently infilled with alluvium, and since coalescing Aliakmon and Axios deltas began to hinder the easy flow of the Ludias, and of the Axios itself, both rivers preferred the more accessible base-level provided by the Pella/Giannitsa depression. Strabo identifies the main freshwater source for this large Ludias Lake as one arm of the Axios. The Ludias river (upper), sometimes distinguished from now on as the Roedias (e.g. Pliny), avoided hindrance by the Aliakmon delta, and emptied into the Lake as well. Eustatic sea-level rise raised the plain watertable, encouraging permanent standing water in the lowlying Lake area. Since this depression existed till Struck's time, while Medieval floodplain aggradation increasingly hindered the flow of the main rivers, the Lake had naturally a long life, a major arm or the whole of a river frequently emptying into the depression rather than the receding Gulf.

Edson demonstrates that throughout these centuries from Herodotus to Strabo, communications avoided the central plain. Clearly there was no choice, and the early Imperial route indicates how late this situation prevailed. Hinterland alluviation postdates Neolitic ditch silting at Nikomedeia, but was certainly operating during or after Roman times at Nisi, after the Medieval bridge at Tschülhalar was abandoned (Struck 1908, 12) and after the construction of post-Medieval corn magazines noted by Cousinery $\left(\mathrm{r}_{3} \mathrm{r}, 66\right)$. The consistent dating for recent hinterland and upstream alluviation throughout Greece by this writer, thoughout the Mediterranean by Vita-Finzi, is a Late Roman commencement, an early modern cessation. The Nikomedeia and Nisi dates with the later examples, could fit comfortably into this chronology. The apparent change in the nature of the plain during Late Roman times, allowing the construction of a major road and bridge across the lower delta zone, coincides remarkably with the contemporary heavy build up of plain alluvium throughout Greece. Edson suggested a political background to this engineering feat (1955, 180), and considering how 


\section{7 . Bintliff. THE PLAIN OF WESTERN MACEDONIA}

previous road systems avoided the inner plain, claimed the new road as a notable technological achievement - we confidently prefer the evidence for a natural change in the depth and firmness of plain alluvium at this time. It was a change in climate, with overloaded rivers aggrading, that created a far greater depth of sediment at every stage of the rivercourses (fig. roe; Bintliff $1975 \mathrm{~b}, 1976 \mathrm{a}$ ).

Limited local dating evidence appears to agree with the chronology of such changes elsewhere. We can also consider the core and its record of sedimentation rates. Upper $\mathrm{Z}_{1}$ records the appearance of the freshwater Ludias Lake, this event being placed in the final few centuries B.c. Beginning at the $\mathrm{Cr}_{4}$ dated level of $c$. $10 \mathrm{~m}$ down in the core- $7270 \mathrm{bp}$ (perhaps $8400 \mathrm{BP}$ )-then noting the ievel of upper $\mathrm{ZI}-c .4 .5 \mathrm{~m}$ down and $c$. 300-I B.C., finally the top of the core at $c$. 1900 A.D.; the average rate of sediment accumulation in the first 6000 years from the first dated level, is less than a metre per millennium. In contrast sediment accumulated during the last $2-2 \frac{1}{2}$ millennia probably equals twice that level.

The latest phase in the alluviation cycle, a return to drier more 'Mediterranean' climate (VitaFinzi 1969), occupies the last few centuries. Streams are now less burdened with sediment, and their previously established steep courses begin to be downcut. Due to drainage and canalisation it is difficult to detect the presence or absence of natural downcutting along the rivers in the plain. Mercier, in his geological study of the hill-land around the plain's northern edge, does provide a typical cross-section of a river valley in that area $(1973,580 \mathrm{ff}$; fig. $\mathrm{II})$. He isolates two major alluvial terraces. The higher is a Quaternary fluviatile formation, related to extensive reddish colluvia and alluvia throughout this hill country; this compares well to the Würm Older Fill formation of VitaFinizi. A lower terrace lies immediately above the riverbed. This Mercier relates to the surface alluvium of the plain and other recent valley fill terraces. It compares closely to the Historical Alluvial Formation of Vita-Finzi, and corresponds to the Late Roman-Medieval stream aggradation phase. The river has incised through two or so metres of recent alluvium here since the recommencement of the downcutting regime.

Figure rof illustrates this last phase. The lake has shrunk without the influx from the major rivers. In the last $1_{50}$ years records suggest renewed deltaic extension along the Thermaic Gulf (e.g. Struck $1908,6,98)$, predictable for the changed river regime. This coincides with downcutting along the rivercourses.

Our reconstruction necessarily departs from previous schemes for the Plain's Holocene development.

Struck's maps (fig. 8) we criticize particularly for: no junction of Ludias and Aliakmon; a too extended Gulf (8a); existence of Lake Ludias unlikely before Strabo's time (8b). Bottema's version (fig. 6) seems unacceptable: a too extended Gulf in prehistoric and early historic times, no later junction of Aliakmon and Ludias (6a-b); excessively enlarged Ludias Lake c. 500 A.D., especially when Bottema shows the Lake not receiving substantial freshwater from the Axios or Aliakmon (6c); an incorrect delimiting of Lake Giannitsa c. 1900 A.D. - compare Struck's 1908 map (fig. Io f), and we see that the Bottema Lake does not even overlap with Struck's! A marshy area extended towards Nikomedeia, but was rarely affected by openwater conditons (6d; cf. fig. ro f). Prof. Hammond's maps we criticize as follows: his interpretation of the 'narrow stretch of land' at Pella is acceptable, but the path of Ludias to Aliakmon, and the direction of the latter, are mere guesswork (fig. 7 b); contemporary sea-level, the nature of deltaic deposits, an attraction to the subsidence zone by Pella, would narrowly control these rivers. Hammond's later map (fig. 7a), supposedly illustrates Strabo. We challenge the narrow passage of the Ludias River to Lake Ludias-hardly a major shipway! The exaggerated infill of the coastal plain is refuted by the prolonged route diversion round the north side of the plain until centuries later. Furthermore, the Strabo situation can hardly predate the second century B.c. when we still have accurate sources such as Livy, where no mention is made of the Lake-certainly a major topographical feature. The other pre-Strabo sources concur. 


\section{A Nero Look at the Prehtstoric Settlement at Nea Nikomedeia}

The excavator's coastal site backed by moist alluvium, must now become an inland site surrounded by well-drained old lacustrine silts. Modern waterlogging in the Neolithic house foundations, the general unsuitability of winter occupation in the plain, reflect a watertable and drainage system unrelated to the prehistoric situation, when no problems were experienced with groundwater, or movement and tillage in the plain soils around the tell. The correlation of a summer occupation with marine activities and grazing herds on seasonally-dry estuary marshes, should now be rejected for winter occupation correlated with the cultivation of winter and spring crops. It is more probable that coastal resources were culled from another location actually on the coast, and quite possibly a summer site for the Nikomedeia farmers.

We find further confirmation for this reinterpretation from the study of Shackleton (1970). We can now explain the apparent paradox that although 'the low land near the site ... may have been occupied ... by a lake ... or an arm of the Gulf of Thermai', 'shellfish remains are not abundant in the deposits' and 'at this particular site we are limited by the fact that shellfish was not an important part of the diet' (1970, 943-4). Shackleton's report includes an analysis of cockle shells from the site levels and their isotopic composition. The climatic implications of such an analysis, he says, may provide us with a clue in the future about the season of the year when the site was occupied. He neglects to comment on the 13 sample shells, but in figure 12 an interesting comparison may be made between the yearly seasonal range of isotopic content in one shell, and the apparent composition of the 13 shells at the season of capture. Eight of the 13 cockles were collected in winter, four could be spring or autumn, none full summer.

We can also comment on the locational significance of Pella. In its hinterland, this site disposed of extensive Tertiary sediments of great agricultural fertility. To the south the site had good access to the sea, even if the distance from the open Gulf grew longer. With the Late Roman consolidation of the plain alluvium, we must assume that Pella's harbour importance disappeared, certainly favouring the rise of Thessalonika to regional pre-eminence during these centuries. However the Pella location was astride the major Via Egnatia route, was centrally placed for servicing a large hinterland zone, and continued to dominate fertile hill-land. With continuing alluvial aggradation in the Medieval period, the edge position of Pella became the necessary norm of the Plain's towns-to avoid the insects and plagues of the moist alluvium, the depredations of the shifting rivers. Giannitsa town, not far to the west of Pella, reflects a similar locational design to its predecessor-a hinterland of Tertiary soils, and an interest in the plain bottomland before it. In recent centuries this bottomland has become firmer and drier, both from natural drainage action and the hand of Man, and the custom of seasonal farming from the secure plain edge settlements has yielded to agricultural settlements placed amid the bottomland itself. This is also connected to the novel importance of irrigated crops, e.g., vegetables for Thessaloniki, as opposed to a former concentration on staple cereals and olive-oil. The dry Tertiary hills support flourishing cereals and olives, but the moister, more acidic bottomland alluvium is better suited to root crops, rice and cotton. Olives and citrus are absent from the plain proper, attributed to lowland frosts and fogs (Admiralty 1945,116 ). The present abundance of cereals throughout the bottomland reflects the dramatic reclamation achieved this century, and the restrictions on olive and fruit trees.

However, a major conclusion from our researches has been to establish a long history and prehistory for a very different type of lowland environment, characterized by dry lacustrine silts. This formation would produce a soil identical to that on the Tertiary hill-land today, pre-eminently cereal and olive land. Arguably, the bottomland mists and frosts are stimulated by an abnormally high watertable and poor drainage, and in previous millennia, such conditions being generally absent, atmospheric affects would not have hindered extensive olive production throughout the western plain. 


\section{IO. 7 . Bintliff. THE PLAIN OF WESTERN MACEDONIA}

This brings us to the question of natural vegetation in the lowlands. Bottema reconstructs the early prehistoric plain: 'the first farmers ... found the area covered with deciduous forest ... to the east and north-east, the forest gave way to swamp forest ... [and] saline meadows' $(1974,146-7)$. In Bottema's view the original pollen interpretation, which compared the Neolithic picture to the present day one, erred on sampling and conclusions. Furthermore, the present day vegetation is in no way a natural one, as Rodden assumes. The lowlands are almost treeless 'steppe', but we need not go very far back to discover a quite different picture.

Cousinery $\left(18{ }_{3} \mathrm{I}\right)$ saw plentiful woods from Verroia to the sea, along the Aliakmon (62): Bottiaea (the plain) is 'almost all wooded' $(64)$; in the plain he saw 'amid woods good harvests of corn in fields' (68); 'all the western plain ... [is] ... woods and fields' (78). Also around this time, during a disastrous shift in the Aliakmon's course, a forest and 200 houses disappeared (Bottema 1974, 75).

Struck mentions forests north of Klidhi, water-adapted varieties, Salix, Populus, Platanus and Ulmus; also a heavy forest of Fraxinus and other trees near Stavros (near Nikomedeia) (Bottema 1974, 177). Makatsch (1950) provides old records of woodland birds of prey in the latter area and Bottema reports local people affirming far more extensive woodland, especially of Fraxinus (deciduous ash) for the pre-1939 period. Bottema concludes that swamp forests were more frequent on the wetter soils, deciduous forests on drier and higher parts of the plain.

Striking confirmation comes from Bottema's vegetational sequence in the Giannitsa core (1974, 142-6). Forest cover correlates more with hydrological changes in the plain, than with any other factor. The incursion of the Thermaic Gulf, in the early core, and the formation of Lake Ludias/ Giannitsa, in the later phases, have most affect on the plain's woodland. Changes in the proportions of different tree species may indicate human interference, but the general picture of forest regeneration is constant throughout the sequence. There is no trace of the present day open plain environment, and Bottema concludes: 'a comparison of surface sample 12 with the upper spectra of the Giannitsa diagram, indicates that large scale deforestation took place rather late'; indeed there is no comparison between full deciduous cover at the top of the core and the poverty of vegetation characterizing the present day plain and its pollen spectrum. A date for this major deforestation between the mid-nineteenth century and $c$. I939 A.D. seems most probable. This astonishingly recent alteration in the landscape has its parallels throughout Greece (see Bintliff $1975^{\mathrm{a}}$ and fourthcoming). It would certainly be surprising if the early settlers at Nikomedeia found the plain in its present treeless state, for the lacustrine silts and the low watertable would be even more conducive to flourishing woodland that the recent alluvium.

High proportions of pig and cattle in the Nikomedeia faunal remains, including large and probably wild specimens, surely reflect a strong element of woodland near the site, for both species are well adapted to forest ecology, the pig especially.

\section{BIBLIOGRAPHY}

Admiralty Handbook, 1945. Naval Intelligence Division, Greece, volume 3.

Bintliff, J. L., 1975a. 'Natural Environment and Human Settlement in Prehistoric Greece'. Ph.D. thesis, Cambridge University.

r975b. 'Mediterranean Alluviation: New Evidence from Archaeology', PPS, 41, 78-84.

1976a. 'Sediments and Settlement in Southern Greece'. In D. Davidson and M. Shackley (ed.), Geoarchaeology (in press).

1976b. 'New Approaches to Human Geography: Prehistoric Greece, A Case-Study'. In F. Carter (ed.), The Historical Geography of the Balkans (in Press).

Bottema, S., 1974. Late Quaternary Vegetation History of Northwestern Greece. Groningen.

Butzer, K. W., 1971. Enviromment and Archaeology. Chicago and N.Y. 
Casson, S., 1926. Macedonia, Thrace and Illyria. Oxford.

Cousinery, E. M., 1831. Voyage dans la Macédoine. T.prem.Paris.

Cvijic, J., 1908. 'Grundlinien der Geographie und Geologie von Mazedonien und Altserbien r', Pet.Mitt.ErgH., 162. Gotha.

Deltion Archaologiki, r964, r9, B3, p.359.

Edson, C., 1955. 'Strepsa', Class.Philology, 50, 169-9o.

Hammond, N. G. L., 1972. A History of Macedonia, Vol. x. Oxford.

Higgs, E. S., et al., r967. 'The Climate, Environment and Industries of Stone Age Greece: Part Three', PPS, 33, $1-30$.

Ilitscheff, D. C., 1899. Ein Beitrag zur Geographie von Makedonien. Leipzig.

Isbell, H., r $97 x$. The Last Poets of Imperial Rome. London.

Kraft, J. C., 1972. A Reconnaissance of the Geology of the Sandy Coastal Areas of Eastern Greece and the Peloponnese. Delaware.

Makatsch, W., 1959. Die Vogelvelt Macedoniens. Leipzig.

Mercier, J., 1973 (1968). 'Etude Géologique des zones Internes des Hellénides en Macédoine Centrale', Annales Géologiques des Pays Helléniques, 2o, Prem. Thèse.

Nicod, J., 1963. 'Problèmes de Morphologie Karstique en Grèce', Méditerrannée, 4, 15-25.

Oberhummer, E., 1937. 'Pella', Pauly-Wissovva Real-Encyclopädie der klassischen Altertumswissenschaft, 341-8.

Petsas, P., r960. 'Pella. Literary Tradition and Archaeological Research', Balkan Studies, 1, 113 $_{3}-28$.

Renfrew, A. C., 1973. Before Civilisation. New York.

Rodden, R. J., et al. 1962. 'Excavations at the Early Neolithic Site at Nea Nikomedeia, Greek Macedonia (1961 Season)', $P P S, 28,267-88$.

Rodden, R. J., 1964. 'Recent Discoveries from Prehistoric Macedonia (an interim report)', Balkan Studies, 5, rro-24.

1965. 'An Early Neolithic Village in Greece', Scientific American, 212, 4, 83,-91.

Schmid, E., 1965. 'Die Seidi-Höhle, Eine Jungpaläolithische Station in Griechenland', Compte Rendu du Colloque Int.de Spéléologie, 4, $163-74$. Athens.

Schmidt, J., 1893. 'Aigai', Pauly-Wissowa Real-Encyclopädie der klassischen Altertumswissenschaft, 944.

Shackleton, N., r970. 'Stable Isotope Study of the Palaeoenvironment of the Neolithic Site of Nea Nikomedeia, Greece', Nature Lond., 227, 943-4.

Struck, A., 1908. Makedonische Fahrten, 2: Die Mak.Niederl. Sarajevo.

Vita-Finzi, C., 1969. The Mediterranean Valleys. Cambridge. 